\title{
Degradation of E2F by the ubiquitin-proteasome pathway: regulation by retinoblastoma family proteins and adenovirus transforming proteins
}

\author{
Guus Hateboer, ${ }^{1,2}$ Ron M. Kerkhoven, ${ }^{1}$ Avi Shvarts, René Bernards, ${ }^{3}$ and Roderick L. Beijersbergen \\ Division of Molecular Carcinogenesis, Netherlands Cancer Institute, 1066 CX Amsterdam, The Netherlands
}

E2F transcription factors are key regulators of transcription during the cell cycle. E2F activity is regulated at the level of transcription and DNA binding and by complex formation with the retinoblastoma pocket protein family. We show here that free E2F-1 and E2F-4 transcription factors are unstable and that their degradation is mediated by the ubiquitin-proteasome pathway. Both E2F-1 and E2F-4 are rendered unstable by an epitope in the carboxyl terminus of the proteins, in close proximity to their pocket protein interaction surface. We show that binding of E2F-1 to pRb or E2F-4 to p107 or p130 protects E2Fs from degradation, causing the complexes to be stable. The increased stability of E2F-4 pocket protein complexes may contribute to the maintenance of active transcriptional repression in quiescent cells. Surprisingly, adenovirus transforming proteins, which release pocket protein-E2F complexes, also inhibit breakdown of free E2F. These data reveal an additional level of regulation of E2F transcription factors by targeted proteolysis, which is inhibited by pocket protein binding and adenovirus early region 1 transforming proteins.

[Key Words: E2F; ubiquitin; cell cycle]

Received July 25, 1996; revised version accepted October 21, 1996.

E2F transcription factors control the expression of at least three groups of genes that are involved in cell cycle regulation. First, E2F sites have been found in the promoter of the immediate early gene c-myc (Hiebert et al., 1989; Oswald et al. 1994). In addition, E2F contributes to the regulation of several genes whose expression is activated in the $G_{1}$ phase of the cell cycle, including cyclin E, E2F-1, and p107 (Johnson et al. 1994b; Neuman et al. 1994; Degregori et al. 1995; Zhu et al. 1995b; Botz et al. 1996). Finally, E2F contributes to the cell cycle-regulated expression of a number of genes that are required during $\mathrm{S}$ phase, such as cyclin $\mathrm{A}$, dihydrofolate reductase, DNA polymerase $\alpha$, and thymidine kinase (for review, see Farnham et al. 1993). E2F transcription factors are heterodimers that contain one of five related E2F polypeptides and one of two DP polypeptides (for review, see Beijersbergen and Bernards 1996).

The activity of the various E2F transcription factors is regulated at three different levels. First, the abundance of $\mathrm{E} 2 \mathrm{~F}$ is regulated at the level of transcription. For exam-

\footnotetext{
${ }^{1}$ These authors contributed equally to this work. ${ }^{2}$ Present address: European Institute of Oncology, Department of Experimental Oncology, 20141 Milan, Italy.

${ }^{3}$ Corresponding author.
}

ple, E2F-4 is the most prominent E2F species in quiescent cells, whereas E2F-1 is absent in quiescent cells but is transcriptionally induced following mitogenic stimulation in late $\mathrm{G}_{1}$ (Johnson et al. 1994; Sardet et al. 1995). Second, transactivation by E2Fs is negatively regulated by complex formation with one of three members of the retinoblastoma family, pRb, p107, and p130, collectively known as the pocket proteins (for review, see Beijersbergen and Bernards 1996). E2F-1, 2, and 3 interact preferentially with pRb; E2F-4 with p107 and p130 (Beijersbergen et al. 1994; Ginsberg et al. 1994; Vairo et al. 1995); E2F-5 with p130 only (Hijmans et al. 1995). These E2Fpocket protein complexes are likely to perform different functions during the cell cycle as the timing of their appearance differs. Most quiescent cells have one major E2F complex that consists of E2F-4 in complex with p130 (Chittenden et al. 1993; Cobrinik et al. 1993; Vairo et al. 1995). Exponentially growing cells contain significant amounts of free E2F and E2F-p107 complexes (Lees et al. 1992; Shirodkar et al. 1992; Cobrinik et al. 1993; Beijersbergen et al. 1995). E2F-pocket protein complexes are regulated by phosphorylation of the pocket proteins by $\mathrm{G}_{1}$ cyclin/cyclin-dependent kinase (cdk) complexes. $\mathrm{pRb}$ can be phosphorylated by cyclin $\mathrm{D} / \mathrm{cdk} 4$, cyclin $\mathrm{E} / \mathrm{cdk} 2$, and cyclin A/cdk2 kinase complexes (Hinds et 
al. 1992; Dowdy et al. 1993; Ewen et al. 1993). In contrast, p107 is efficiently phosphorylated only by cyclin $\mathrm{D} / \mathrm{cdk} 4$ (Beijersbergen et al. 1995). In addition, several viral oncoproteins, including adenovirus ElA, can disrupt E2F-pocket protein complexes through high affinity binding to the pocket proteins (Whyte et al. 1988).

A third level of regulation of E2F activity concerns the regulation of DNA-binding activity. E2F-1 can interact directly with cyclin $\mathrm{A}$, which results in phosphorylation of DP-1 in S phase, causing down-regulation of E2F DNA binding activity (Dynlacht et al. 1994; Krek et al. 1994). Down-regulation of E2F in S phase appears to be important in cellular homeostasis, as overexpression of E2F or mutants of E2F that resist cyclin A down-regulation can cause apoptosis and transformation (Beijersbergen et al. 1994; Johnson et al. 1994a; Qin et al. 1994; Singh et al. 1994; Wu and Levine 1994; Krek et al. 1995).

E2F DNA-binding sites in promoters can act as both positive and negative regulatory elements, depending on the promoter context (Lam and Watson 1993). The action of E2F sites as negative regulatory elements is most readily explained by the finding that pocket proteins can mediate active transcriptional repression (Weintraub et al. 1992, 1995; Bremner et al. 1995). Thus, E2F-pocket protein complexes found in quiescent cells may contribute to maintaining quiescence through active transcriptional silencing of growth factor-activated genes.

Many of the proteins that contribute to regulation of the cell cycle appear and disappear rapidly. Unstable proteins are often degraded in a highly regulated fashion by the ubiquitin-proteasome pathway (Jentsch 1992; Hochstrasser 1995; Jentsch and Schlenker 1995; Rubin and Finley 1995; Hilt and Wolf 1996). This system acts by covalent attachment of multiple ubiquitin polypeptides to the substrate. This requires the action of three different enzymes: a ubiquitin-activating enzyme (E1), which binds ubiquitin and transfers it to an ubiquitinconjugating enzyme (UBC or E2) (Haas and Rose 1982; Pickart and Rose 1985), which in turn may need the assistance of a ubiquitin ligase (E3) to attach the ubiquitin residue covalently to the substrate (Scheffner et al. 1993). Multiubiquitination acts as a sorting signal that targets substrates for rapid degradation by the proteasome /Chau et al. 1989).

An important link between the ubiquitin-proteasome machinery and cell cycle regulation came from the finding that $C D C 34$, a yeast gene required for the $G_{1}$ to $S$ transition, was identical to yeast UBC3, a ubiquitin-conjugating enzyme (Goebl et al. 1994). Other substrates of Cdc34 include yeast $G_{1}$ cyclins and the cyclin/cdk inhibitor p40 ${ }^{\text {Sicl }}$ (Schwob et al. 1994; Deshaies et al. 1995; Yaglom et al. 1995). In mammalian cells, the p27 cyclin/ cdk inhibitor and cyclin $\mathrm{E}$ were recently shown to be degraded in a cell cycle-dependent fashion by the ubiquitin-proteasome pathway (Pagano et al. 1995; Clurman et al. 1996). In budding yeast, the S-phase cyclin Clb5 and the mitotic cyclin $\mathrm{Clb} 2$ are ubiquitinated through UBC9 (Seufert et al. 1995), and Xenopus mitotic cyclins have also been shown to be degraded through ubiquitination (Glotzer et al. 1991).
We report here that E2F transcription factors are unstable as a result of destruction by the ubiquitin-proteasome pathway and that their degradation is highly regulated. Similar results are reported by Hofmann et al. (this issue).

\section{Results}

p107 and adenovirus E1 increase E2F-4 protein levels

To investigate the effect of p107 expression on E2F-4 protein stability, we transiently transfected C33A cervical carcinoma cells with HA epitope-tagged E2F-4 and DP- 1 expression vectors, in both the presence and absence of p107. The amount of E2F-4 protein was monitored in a Western blot. To be able to distinguish between effects on protein stability versus mRNA stability or transfection efficiency, the amount of protein extract used in the Western blot was normalized to the amount of E2F-4 mRNA that was present in each of the extracts of transfected cells (see Materials and Methods). Figure $1 \mathrm{~A}$ shows that transfection of E2F-4 and DP-1 expression vectors under the control of the CMV promoter yields only low steady-state E2F-4 protein levels. However, coexpression of p107 caused a dramatic increase in E2F-4 protein abundance. Similarly, expression of adenovirus 5 early region 1 (Ad5 E1, which directs expression of both E1A and E1B proteins), caused a significant increase in E2F-4 protein level. Because in this experiment the amount of E2F-4 mRNA in the different transfections was normalized (Fig. 1B), these data indicate that expression of p107 or Ad5 El causes an increase in the abundance of E2F-4 protein at equal mRNA levels. This suggests that p107 and Ad5 E1 influence either E2F-4 and DP-1 mRNA translation or protein stability. The observed effects are not restricted to C33A cervical carcinoma cells, as essentially the same results were obtained in U2-OS osteosarcoma cells, Hep-3B hepatoma cells, and NIH-3T3 fibroblasts (data not shown).

\section{p107 and adenovirus E1 stabilize E2F-4 and DP-1 proteins}

To investigate the effect of p107 on E2F-4 and DP-1 protein stability, we performed a pulse-chase experiment. C33A cells were transiently transfected with HA-tagged E2F-4 and DP-1 expression vectors in the presence or absence of HA-tagged p107. Thirty-six hours after transfection, cells were pulse-labeled with $\left[{ }^{35} \mathrm{~S}\right]$ methionine and chased with excess nonradioactive methionine for the indicated time periods. Figure $2 \mathrm{~A}$ shows that E2F-4 protein has a short half-life in the absence of cotransfected p107, whereas coexpression of p107 significantly increased the half-life of both E2F-4 and DP-1. Because in transiently transfected cells E2F-4, DP-1, and p107 readily form a trimeric complex, these data indicate that binding of p107 to E2F-4-DP-1 extends the half-life of these two proteins (Beijersbergen et al. 1994, 1995). Coexpression of Ad5 E1 also caused an increase in E2F-4 and DP-1 half-life (Fig. 2B). We quantitated the intensi- 
A

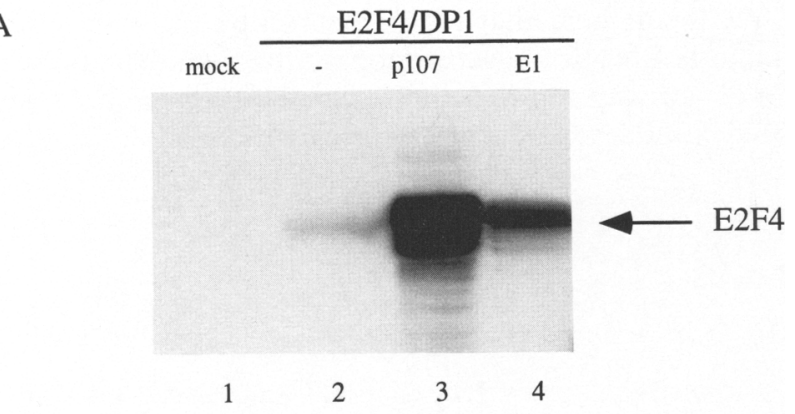

B

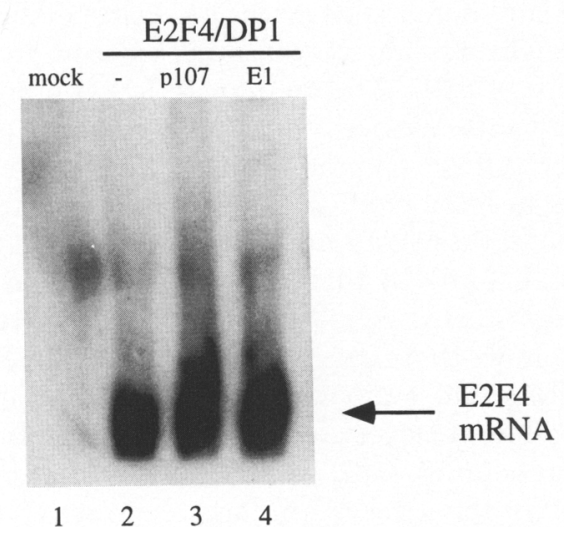

Figure 1. Effect of pl07 and adenovirus E1 proteins on E2F-4 abundance. $(A)$ C33A cells were transfected with $0.5 \mu \mathrm{g}$ of pRcE2F-4, $0.5 \mu \mathrm{g}$ of pCMV-DP-1 in combination with $5 \mu \mathrm{g}$ pCMVHA-p107, or $5 \mu \mathrm{g}$ p5Xhocc4 (encoding Ad5 E1) as indicated. Thirty-six hours after transfection, the cells were lysed and cell extracts were subjected to $7.5 \%$ SDS-PAGE. The separated proteins were transferred to nitrocellulose and E2F-4 protein was detected by Western analysis with polyclonal antibody C-108. The amounts of protein extract used in this experiment were normalized for mRNA levels present in transfected cell extracts (see below and Materils and Methods). (B) Northern blot of RNA from transiently transfected cells as in $A$, probed with E2F-4 cDNA after normalization for equal amounts of E2F-4 mRNA (see Materials and Methods section).

ties of the bands using a PhosphorImager. The results of three independent experiments are displayed in Figure 2C. These data indicate that free E2F-4 has a half-life of $\sim 2-3 \mathrm{hr}$, whereas p107 and Ad5 E1 increase the half-life to $\sim 8$ and 10-12 hr, respectively. We conclude that p107 and Ad5 E1-encoded proteins interfere with proteolysis of E2F-4 and DP-1 proteins.

\section{Stabilization of E2F-4 correlates with pocket protein binding}

To ask whether stabilization of E2F-4 was correlated with pocket protein binding, we transfected E2F-4 with either wild-type or mutant p107 expression vectors. E2F-4 protein levels were monitored by Western blot analysis. Figure $3 \mathrm{~A}$ shows that cotransfection of E2F-4 with wild-type p107, p107-N385, or p107- $\Delta 27$, all of which can bind E2F-4 (Zhu et al. 1995a), causes E2F-4 to accumulate at higher levels. In contrast, p107- $\Delta 28$, which does not bind E2F-4 (Zhu et al. 1995a), failed to increase E2F-4 protein abundance even though this mutant was expressed at the same level as the other p107 mutants (Fig. 3A, top panel).

The complex between E2F-4 and p107 is disrupted by phosphorylation of $\mathrm{p} 107$ by cyclin $\mathrm{Dl} / \mathrm{cdk} 4$, but not by cyclin $\mathrm{A} / \mathrm{cdk} 2$ or cyclin $\mathrm{E} / \mathrm{cdk} 2$ (Beijersbergen et al. 1995). We therefore asked whether expression of these cyclin/cdks would affect the ability of p107 to stabilize E2F-4. Figure 3B shows that expression of cyclin Dl/ cdk4 prevents the p107-mediated increase in E2F-4 abundance. In contrast, both cyclin $\mathrm{E} / \mathrm{cdk} 2$ and cyclin A/cdk2 expression failed to interfere with p107 stabilization of E2F-4 (Fig. 3B).

In quiescent cells the major E2F-4 pocket protein complex is E2F-4-p130 (Cobrinik et al. 1993; Vairo et al. 1995). We therefore asked whether p130 shared with p107 the ability to stabilize E2F-4 protein. Figure $3 \mathrm{C}$ shows that expression of p130 caused a similar increase in E2F-4 protein levels as p107. Furthermore, phosphorylation of both pocket proteins by cyclin D1/ cdk4 abolished pocket protein-mediated stabilization of E2F-4, whereas expression of cdk4 dominant-negative was without effect (Fig. 3C). Taken together, these data strongly support the notion that E2F-4 is stabilized as a result of direct binding to a pocket protein partner.

\section{A carboxy-terminal epitope renders E2F-4 unstable}

The data shown above indicate that E2F-4 is unstable and that binding of pocket proteins to the carboxyl terminus of E2F-4 causes an increase in E2F-4 half-life. We therefore asked whether a carboxy-terminal deletion mutant of E2F-4, $\triangle E 2 F-4$ encoding amino acids 1-301 of E2F-4 and lacking the p107 interaction surface, differed from wild-type E2F-4 in stability. Figure 4A, lanes 2 and 4 , show that, after normalization for mRNA levels in transfected cells (right panel), $\Delta \mathrm{E} 2 \mathrm{~F}-4$ was expressed at a substantially higher level as compared with wild-type E2F-4 (left panel). Pulse-chase experiments using both wild-type E2F-4 and $\Delta$ E2F-4 transfected cells indicated that this difference in protein accumulation was caused by a significantly prolonged half-life of the $\Delta \mathrm{E} 2 \mathrm{~F}-4$ protein as compared with the wild-type E2F-4 protein $(2 \mathrm{hr}$ vs. $18 \mathrm{hr}$, Fig. 4B,C). Thus, the carboxy-terminal 112 amino acids of E2F-4 harbor an epitope that renders the protein unstable. Significantly, expression of p107 caused an increase in wild-type E2F-4 abundance, but did not affect protein levels of $\Delta \mathrm{E} 2 \mathrm{~F}-4$ (Fig. $4 \mathrm{~A}$, lanes 3 and 5). As an additional control for specificity, we show in Figure $4 \mathrm{C}$ that the abundance of $\mathrm{p} 27$, a labile nuclear protein that does not interact with p107 (Polyak et al. 1994; Toyoshima and Hunter 1994), was also not affected by p107. Taken together, these data support the notion that binding of E2F-4 to p107 causes the protein to be stable and that p107 does not influence protein stability nonspecifically. 
A

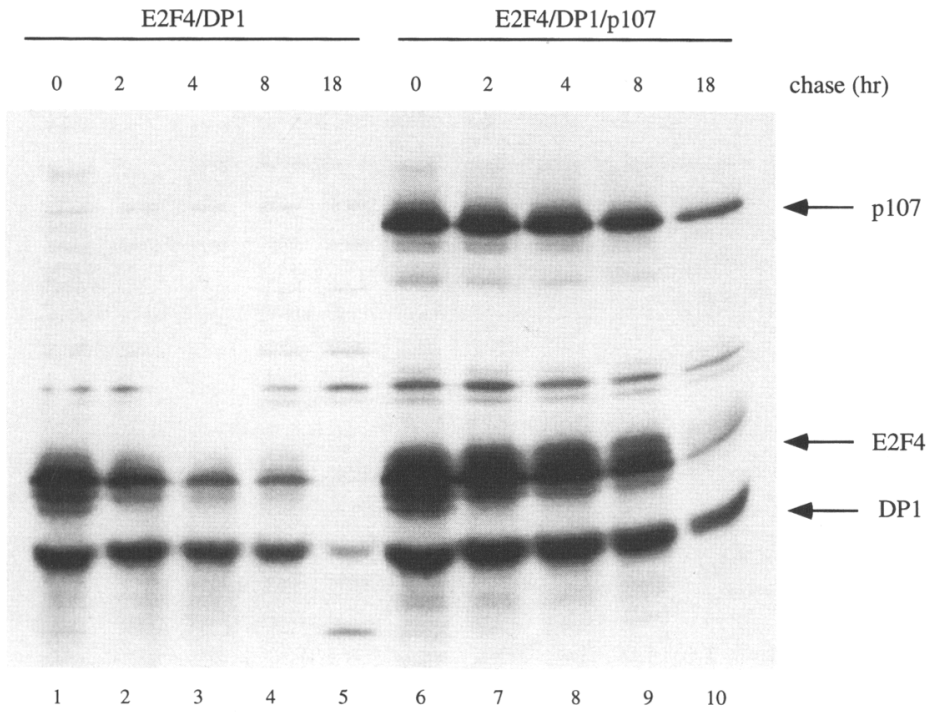

C

B

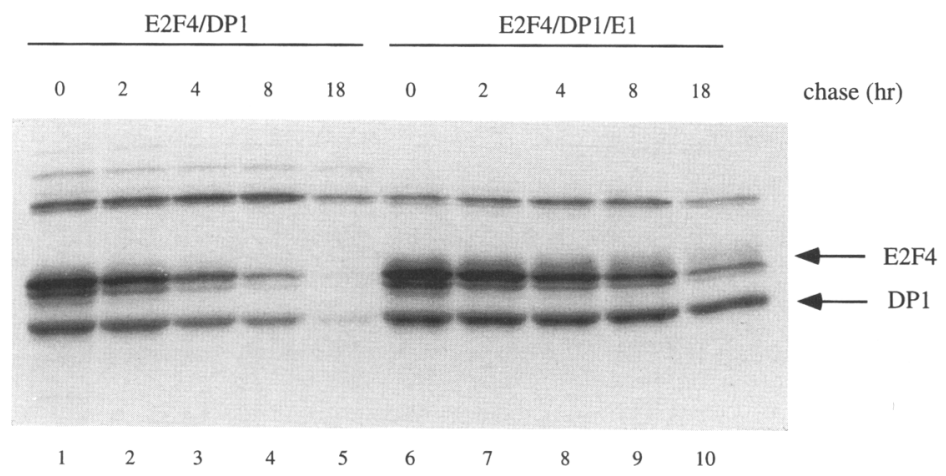

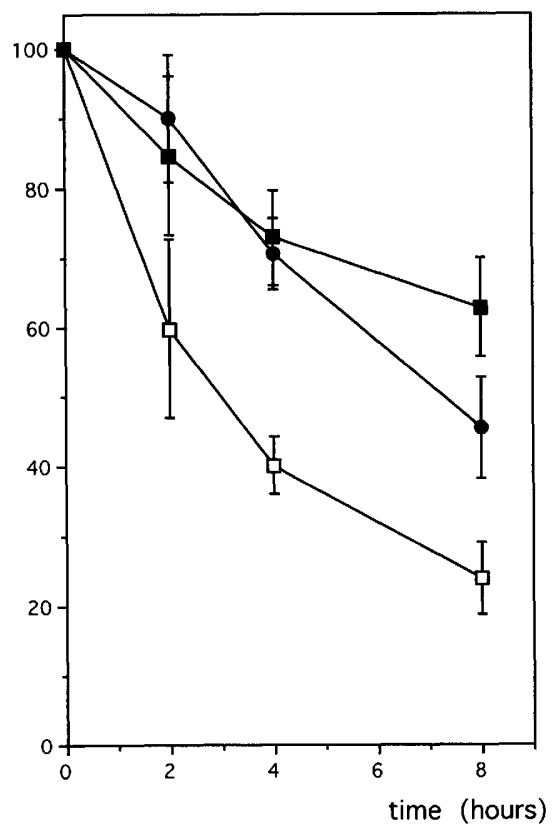

Figure 2. Effect of p107 and adenovirus E1 proteins on E2F-4 and DP-1 half life. (A) C33A cells were transfected with $3.0 \mu \mathrm{g}$ of pRc-HA-E2F-4 and $1.0 \mu \mathrm{g}$ of pCMV-HA-DP-1 in combination with $10 \mu \mathrm{g}$ pCMV-HA-p 107 or $(B)$ with $10 \mu \mathrm{g}$ p 5 Xhocc 4 as indicated. Thirty-six hours after transfection cells were pulse-labeled for $2 \mathrm{hr}$ with a $\left[{ }^{35} \mathrm{~S}\right]$ methionine-cysteine mix. Chase was performed in normal medium supplemented with 10 -fold excess of cold methionine and cysteine for the indicated time periods. Cells were lysed and immunoprecipitations were performed with mAb 12CA5, directed against the HA-epitope. Immunoprecipitated proteins were separated by $10 \%$ SDS-PAGE. (C) The intensities of the $\left[{ }^{35} \mathrm{~S}\right]$-labeled proteins were measured after exposure to PhosphorImager plates and calculated in comparison to proteins present at time point zero. (ㅁ) E2F-4/DP-1; (O) E2F-4/DP-1/p107; (ㅁ) E2F-4/DP-1/Ad5 E1. Shown are the average data from three independent experiments.

\section{E2F-1 and E2F-4 stability is similarly affected by pocket proteins}

Next, we asked whether E2F-1 was similarly affected by expression of its pocket protein partner, $\mathrm{pRb}$, and by Ad5 E1. We transfected HA-tagged E2F-1 and DP-1 expression vectors in the presence of both $\mathrm{pRb}$ and $\mathrm{Ad} 5 \mathrm{E} 1$ expression vectors and monitored E2F-1 and DP-1 protein abundance in a Western blot. Again, expression of $p R b$ and Ad5 E1 greatly increased E2F-1 and DP-1 protein levels (Fig. 5A). Thus, it appears that E2F-4 and E2F-1 are similarly affected by pocket protein expression and by Ad5 E1.

To ask whether in E2F-1 also a carboxy-terminal epitope renders the protein unstable, we used two carboxy-terminal deletion mutants of E2F-1. These mutants were tested for protein expression levels in transient transfection assays. Figure 5B shows that both E2F-1 (1$284)$ and E2F-1 (1-374) are expressed at significantly increased levels as compared with wild-type E2F-1 (1-437). In this experiment, the mRNA levels of wild-type and mutant E2Fs were also equivalent (not shown). We conclude therefore that an epitope in the carboxy-terminal 63 amino acids of E2F-1 renders the protein susceptible to rapid degradation.

Because the $\mathrm{pRb}$ binding site on E2F-1 overlaps with the degradation signal in the carboxyl terminus of E2F-1, we tested whether the carboxy-terminal deletion mutants of E2F-1 could still be stabilized by pRb. Figure 5C and D show that E2F-1 (1-284) and E2F-1 (1-374) protein abundance was not affected by coexpression of $\mathrm{pRb}$. Together, these data suggest that $\mathrm{pRb}$ stabilizes E2F-1 by a mechanism that is similar to the one used by p107 to stabilize E2F-4. 
A
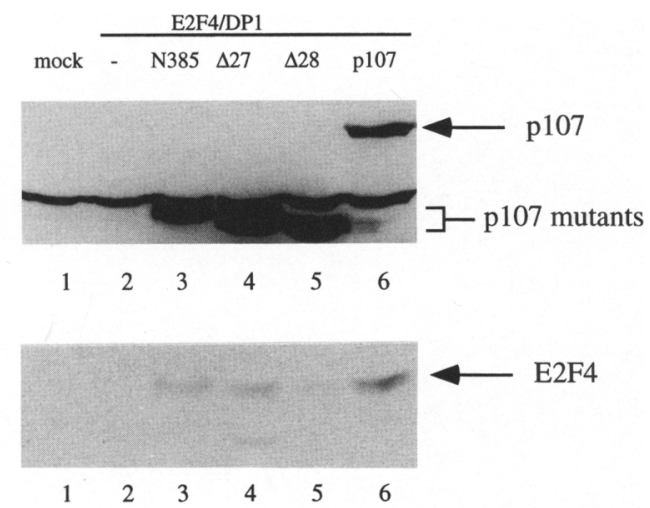

B

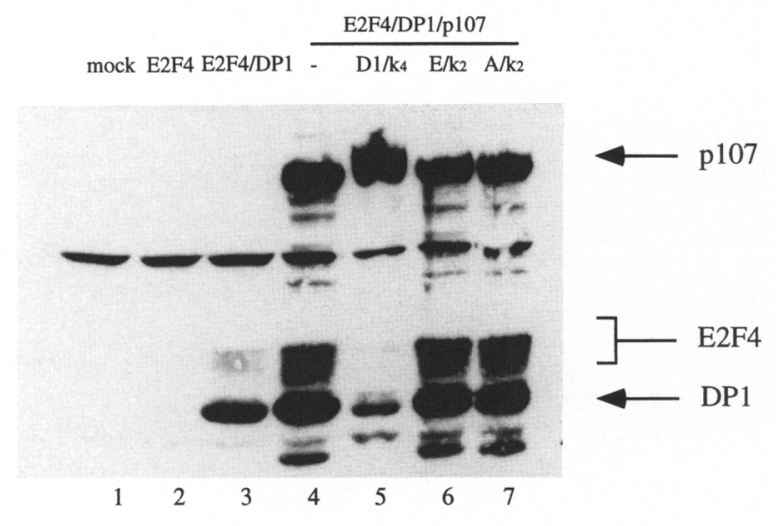

$\mathrm{C}$

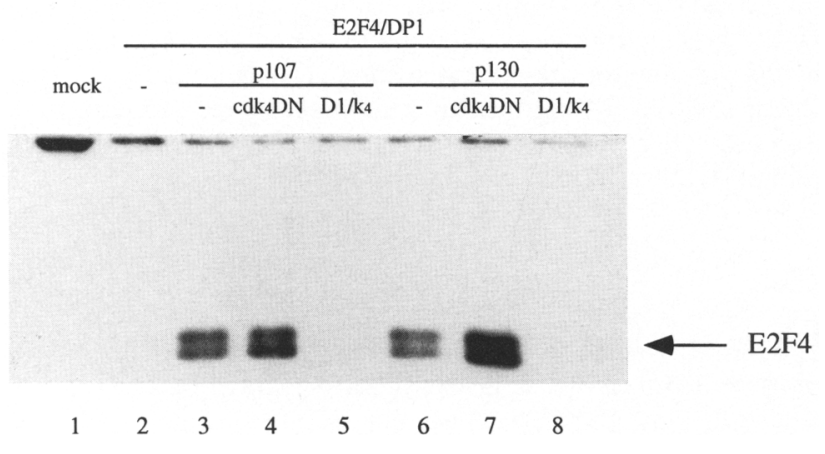

Figure 3. E2F-4 is stabilized through direct binding to p107 and p130. (A). C33A cells were transfected with E2F-4 and DP-1 expression vectors in the presence or absence of wild-type or mutant HA-tagged p107 expression vectors. Protein extracts from transfected cells, normalized for mRNA levels, were separated on a $7.5 \%$ polyacrylamide gel and E2F-4 protein (bottom panel) and the expression level of wild-type and mutant p107 proteins (top panel) were detected with 12CA5 antibody. (B) C33A cells were transfected with HA-E2F-4/HA-DP-1 in the presence of HA-p107 as indicated, together with various cyclin/ cdk combinations as indicated. Transfected E2F-4, DP-1, and p107 proteins were detected in a Western blot with 12CA5 antibody. $(C)$ C33A cells were transfected with HA-E2F-4/DP-1 in the presence of p107 or pl30 as indicated, together with cyclin D1/cdk4 or cdk4-dominant negative, as indicated. E2F-4 was detected in a Western blot with 12 CA5 antibody.
E2Fs are degraded by the ubiquitin-proteasome pathway

Many short-lived cellular proteins are targeted for degradation by the ubiquitin-proteasome pathway. Treatment of cells with proteasome inhibitors should therefore cause an increase in the abundance of proteins that are degraded through this pathway. To ask whether the proteasome is involved in the degradation of E2F-4 in vivo, we treated E2F-4 transfected cells with carboxybenzyl-leucyl-leucyl-leucinal (Cbz-LLL), a potent and specific inhibitor of proteasomes (Rock et al. 1994; Wiertz et al. 1996). E2F-4 protein level was measured by Western blotting. Figure 6A shows that incubation of E2F-4-transfected cells with Cbz-LLL caused a dramatic increase in E2F-4 protein levels as compared with cells treated with solvent only. Similarly, treatment of E2F-1 transfected cells with Cbz-LLL caused an increase in E2F-1 protein levels (Fig. 6C).

A key step in this process involves the covalent attachment of multiple ubiquitin polypeptide chains to the substrate, which targets the substrate for rapid degradation by the proteasome. These ubiquitin-substrate conjugates are highly unstable and can often be visualized only by treatment of cells with proteasome inhibitors. To ask whether E2F-4 is ubiquitinated in vivo, we transfected cells with E2F-4 expression vector (nontagged) and an HA-tagged ubiquitin expression vector. After two days, cell lysates were immunoprecipitated with anti E2F-4 antibody and Western blotted with 12CA5 antibody to detect ubiquitin conjugates. Figure $6 \mathrm{~B}$ shows that a smear of E2F-4-ubiquitin conjugates ranging from $70 \mathrm{kD}$ to several hundred $\mathrm{kD}$ was observed when E2F-4 and HA-tagged ubiquitin were cotransfected and transfected cells were treated with proteasome inhibitor (lane 4). No E2F-4-ubiquitin conjugates were seen when proteasome inhibitor was omitted (lane 5) or when E2F-4 and HA-tagged ubiquitin vectors were transfected separately (lanes 2 and 3 ). Similarly, transfection of E2F-1 and HA-ubiquitin expression vectors resulted in a smear of polyubiquitinated E2F-1 species (Fig. 6D). Together, these data suggest strongly that both E2F-1 and E2F-4 can be polyubiquitinated in vivo and that these E2Fs are degraded by the ubiquitin-proteasome pathway.

\section{Discussion}

We show here that E2F transcription factors are unstable. Two lines of evidence indicate that E2F is a substrate of the ubiquitin-proteasome system of targeted proteolysis. First, incubation of cells with a specific inhibitor of the proteasome leads to a significant accumulation of E2F-1 and E2F-4 protein. Furthermore, we show that in cells treated with proteasome inhibitor, significant amounts of E2F-polyubiquitin conjugates accumulate. Polyubiquitination is known to act as a sorting signal that targets proteins for rapid degradation by the proteasome (Chau et al. 1989). We have mapped the domain that renders E2F-1 unstable to the carboxy-terminal 63 residues, which is in close proximity to the $\mathrm{pRb}$ binding 
A
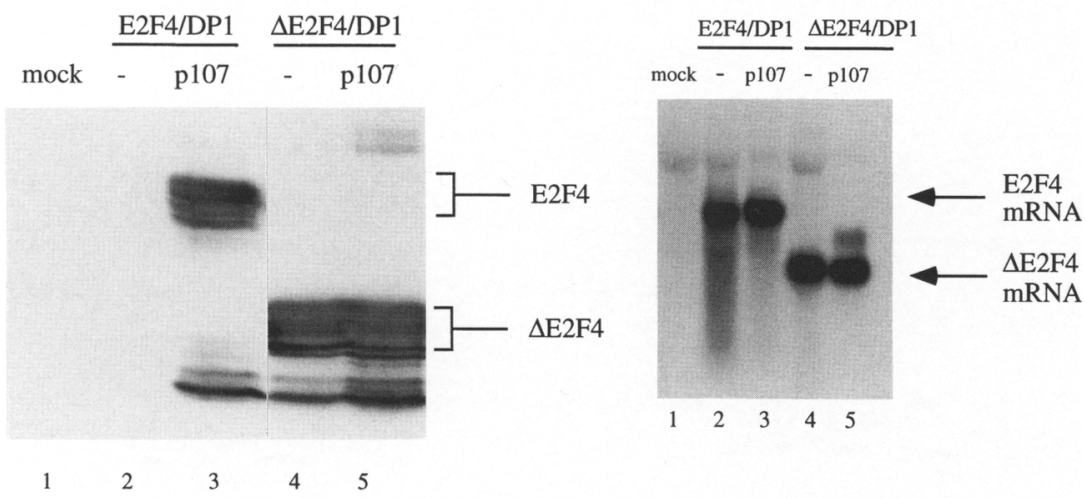

B
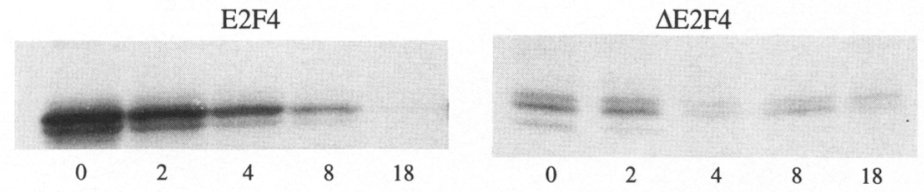

C

D
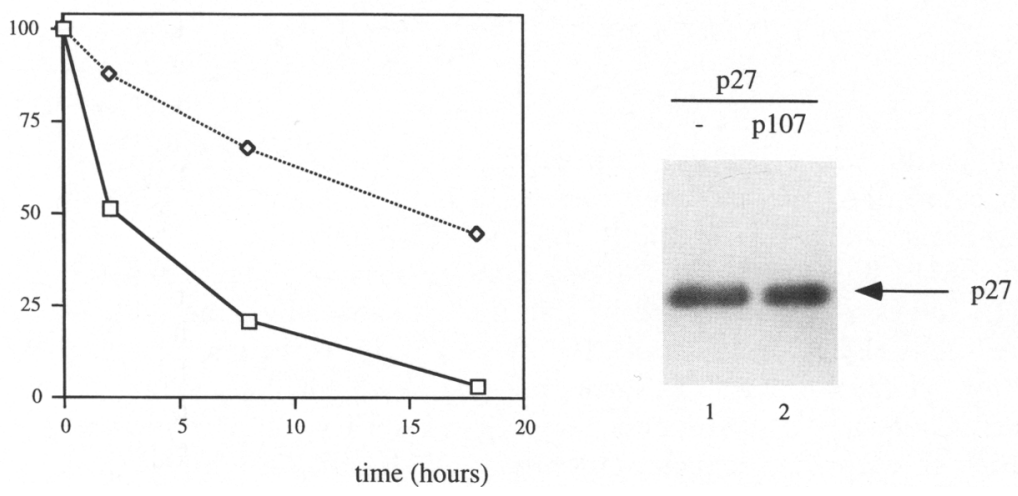

Figure 4. A carboxy-terminal epitope renders E2F-4 unstable. (A, left panel) C33A cells were transfected with E2F-4/DP-1 or $\triangle E 2 F-4$ / DP-1 (expressing amino acids 1-301 of E2F-4) expression vectors in the presence or absence of p107. Protein extracts of transfected cells were normalized for mRNA content. E2F-4 protein was detected in a Western blot with C-108 antibody. (A, right panel) Northern blot of RNA from transiently transfected cells shown in $A$, probed with E2F-4 cDNA after normalization for equal amounts of E2F-4 and $\triangle$ E2F-4 mRNA (see Materials and Methods|. E2F-4 and $\triangle E 2 F-4$ were immunoprecipitated with $12 \mathrm{CA} 5$ antibody. (B) Pulsechase experiment of HA-E2F-4 and $\triangle \mathrm{E} 2 \mathrm{~F}-4$ transfected cells. Cells were pulse-labeled with $\left[{ }^{35} \mathrm{~S}\right]$ methionine-cysteine $\mathrm{mix}$ and chased with excess cold amino acids for the indicated number of hours. (C) Graphic display of intensities of the bands shown in $B$, as determined in a PhosphorImager. $(D)$ Extracts of C33A cells, transfected with HA-tagged p27 expression vector in the presence or absence of p107, normalized for mRNA content. Expression of p27 was detected in a Western blot with 12 CA5 antibody. site of E2F-1 (Helin et al. 1992; Kaelin et al. 1992). Similarly, deletion of the carboxy-terminal 112 amino acids of E2F-4, which includes the p107-p130 binding site, leads to a dramatic increase in E2F-4 half-life. Our data also indicate that binding of $\mathrm{pRb}$ to E2F-1 and binding of p107 or p130 to E2F-4 protects both polypeptides from degradation (Figs. 1-3 and 5). Together, these data suggest a model in which pocket proteins inhibit E2F degradation by shielding a carboxy-terminal epitope on E2F that is recognized by the ubiquitination machinery. Consistent with this, we found that carboxy-terminal deletion mutants of E2F-1 or E2F-4 could not be stabilized further by pocket protein expression (Figs. 4 and 5).
Several proteins whose degradation is cell cycle-regulated become targets for ubiquitin-mediated proteolysis following phosphorylation. Examples are cyclin $\mathrm{E}$ and yeast Cln proteins (Deshaies et al. 1995; Yaglom et al. 1995; Clurman et al. 1996). It is possible that phosphorylation of E2F contributes to susceptibility of E2Fs to ubiquitin-mediated proteolysis. However, a carboxy-terminal deletion mutant of E2F-4, which is significantly more stable than wild-type E2F-4, still displays the same pattern of multiple phosphorylated isoforms as wild-type E2F-4. This makes it unlikely, but does not exclude the possibility, that E2F phosphorylation is important in controlling E2F stability. 
Figure 5. Effect of $\mathrm{pRb}$ and adenovirus $\mathrm{E} 1$ proteins on E2F-1 abundance. $(A)$ C33A cells were transfected with $0.5 \mu \mathrm{g}$ of pCMV-HAE2F-1, $0.5 \mu \mathrm{g}$ of pCMV-HA-DP-1 in combination with $5 \mu \mathrm{g}$ pCMV-pRb or $5 \mu \mathrm{g}$ $\mathrm{p} 5 \mathrm{Xhocc} 4$ as indicated. Thirty-six hours after transfection, the cells lysed and cell extracts were subjected to $7.5 \%$ SDS-PAGE. The separated proteins were transferred to nitrocellulose and HA-tagged proteins were detected by Western analysis with mAb 12CA5. (B). A carboxy-terminal domain renders E2F-1 unstable. C33A cells were transfected with 0.5 $\mu \mathrm{g}$ pRc-E2F-1, $0.5 \mu \mathrm{g}$ pCMV-E2F-1 (amino acids $1-284$ ) or $0.5 \mu \mathrm{g}$ pCMV-E2F-1 (amino acids $1-374$ ), as indicated. Thirty-six hours after transfection, cell extracts were prepared and separated by $7.5 \%$ SDS-PAGE. Proteins were detected by Western blot analysis by using $\mathrm{mAb} \mathrm{KH} 20$, directed against the amino terminus of E2F-1. All transfected proteins are indicated by arrows on the right. $(C, D)$ Effect of pRb on E2F-1 (amino acids 1-284) $(C)$ and E2F-1 (amino acids 1-374) (D). C33A cells were transfected with $2.0 \mu \mathrm{g}$ pRc-E2F-1 (amino acids 1-284), $2.0 \mu \mathrm{g}$ pCMV-E2F- $\mathrm{I}$ (amino acids $1-374$ ), and $2.0 \mu \mathrm{g}$ pRc-DP-1 in combination with $10 \mu \mathrm{g}$ pCMV-pRb as indicated. Thirty-six hours post-transfection, cell extracts were prepared and proteins were separated by $10 \%$ SDS-PAGE and subjected to Western blot analysis using mAb $\mathrm{KH} 20$ directed against an epitope in the amino terminus of E2F-1. Protein extracts used were normalized for E2F-1 mRNA content.
A
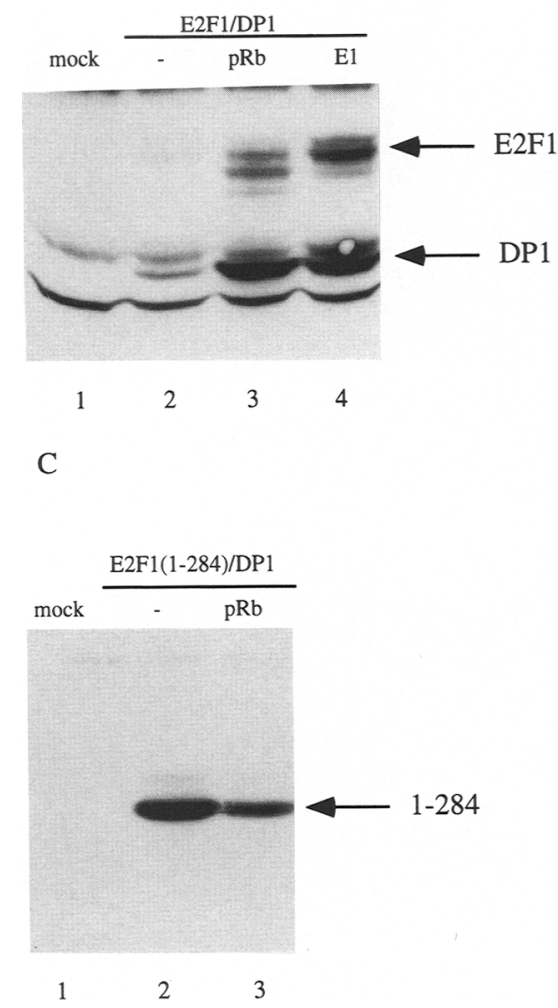

B
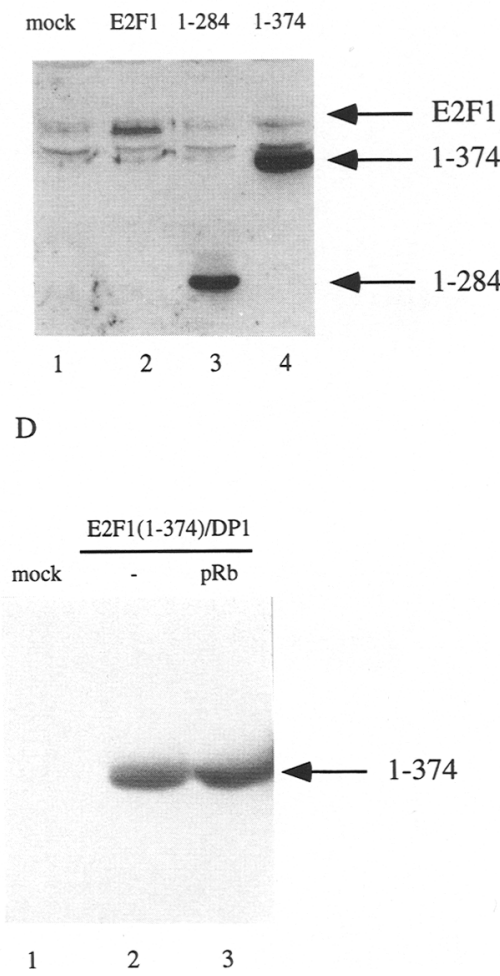

Adenovirus E1 proteins also cause a stabilization of E2F and DP proteins. This was unexpected because E1A is known to disrupt E2F-pocket protein complexes, and should therefore generate free, but unstable, E2F. We propose that the stabilization of E2Fs by Ad5 E1 serves to enhance S-phase entry of adenovirus-infected cells: By preventing the degradation of E2F released from pocket protein complexes, adenovirus El causes a further increase in free E2F transcription factors, which in turn facilitate S-phase entry of adenovirus-infected cells.

How adenovirus early region 1 proteins mediate stabilization of free E2F is at present not clear. We have shown recently that ElA can interact with a member of the family of ubiquitin-conjugating enzymes, named mUBC9, thus providing a possible link between adenovirus transforming proteins and the ubiquitin-proteasome pathway (Hateboer et al. 1996). This protein is highly related to a Saccharomyces cerevisiae protein UBC9, whose inactivation causes an arrest in the $S$ and $\mathrm{G}_{2}$ phases of the cell cycle (Seufert et al. 1995). The ElAinteracting mUBC9 complements the yeast cell cycle defect, indicating that mUBC9 can contribute to yeast cell cycle regulation (Hateboer et al. 1996). It is unlikely, however, that mUBC9 is solely responsible for the observed effect of adenovirus early region 1 on E2F degra- dation, as effective stabilization of E2F requires simultaneous expression of both E1A and E1B genes (G. Hateboer and R. Beijersbergen, unpubl.).

It is unlikely that the observed effects of p107 and Ad5 E1 on E2F-4 stability are caused by nonspecific cell cycle effects of p107 or Ad5 El for three reasons: (1) p107 and Ad5 E1 have opposing effects on cell cycle, but have the same effect on E2F-4 stability. (2) p107 prevents E2F-4 degradation both in C33A cells, in which it causes a $G_{1}$ arrest, and in U2-OS cells, in which p107 does not cause a $G_{1}$ arrest (Fig. 1; Zhu et al. 1993; G. Hateboer and R. Beijersbergen, unpubl.). (3) $\mathrm{A}_{1}$ arrest induced by expression of p27 does not influence E2F-4 stability /data not shown).

Why would pocket proteins prevent degradation of E2F-DP transcription factors? E2F-pocket protein complexes are thought to play an active role in maintaining quiescence by acting as dominant repressors of transcription (Weintraub et al. 1992, 1995; Bremner et al. 1995). As such, E2F-pocket protein complexes may prevent expression of genes that are activated by mitogenic signals. In most types of resting cells, the main E2F that is expressed is E2F-4, which is bound to p130 during quiescence (Cobrinik et al. 1993; Sardet et al. 1995; Vairo et al. 1995) The observed stability to E2F-4-pocket protein 


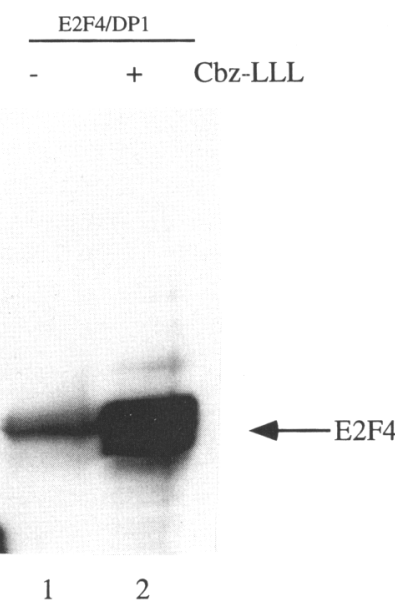

C

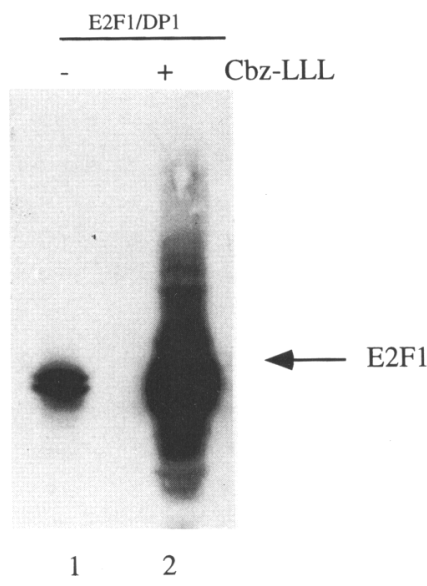

B
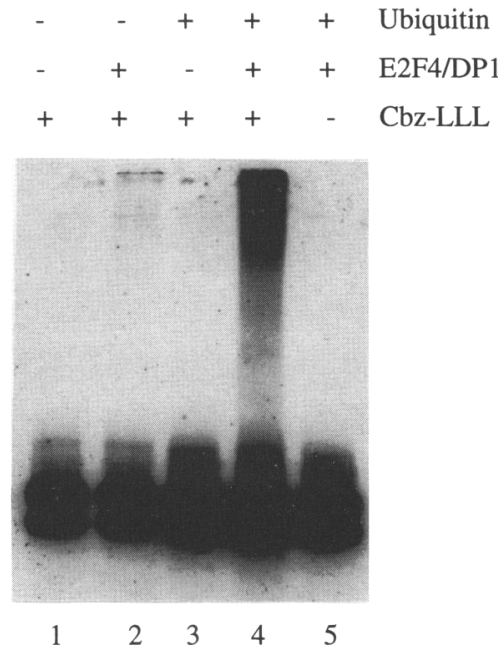

D

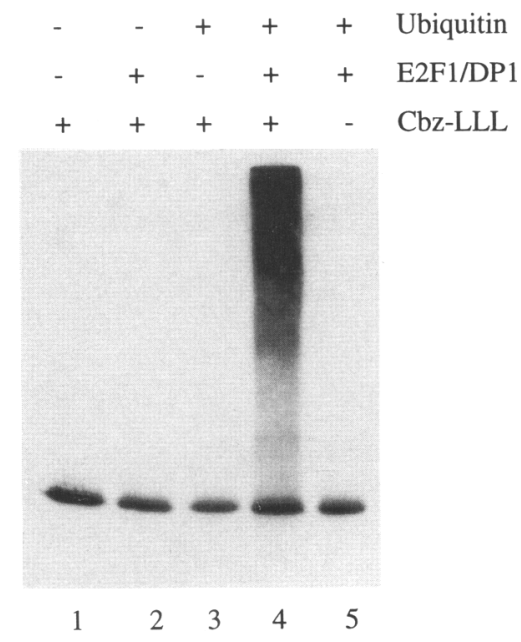

Figure 6. E2F-4 and E2F-1 are targets for the ubiquitin-proteasome pathway. (A) U2-OS cells were transfected with $5.0 \mu \mathrm{g}$ pRc-E2F-4 and $3.0 \mu \mathrm{g}$ pRcDP-1. Twenty-four hours after transfection, cells were incubated in medium supplemented with 10 $\mu \mathrm{M}$ of the proteasome inhibitor Cbz-LLL (lanes 1-4), or medium with solvent only. After $12 \mathrm{hr}$ of incubation, cells were lysed and subjected to Western blot analysis with polyclonal E2F-4 antiserum C-108. $(B) \mathrm{U} 2$-OS cells were transfected with $5.0 \mu \mathrm{g}$ pRc-E2F-4 and $3.0 \mu \mathrm{g}$ pRc-DP-1, together with $5.0 \mu \mathrm{g}$ of pMT123 lexpressing HAtagged ubiquitin protein), as indicated. Twentyfour hours after transfection, cells were incubated in medium supplemented with $10 \mu \mathrm{M}$ of the proteasome inhibitor Cbz-LLL (lanes 1-4), or medium with solvent only. After $12 \mathrm{hr}$ of incubation, cells were lysed and subjected to immunoprecipitation with polyclonal E2F-4 antiserum PCIl and subsequently analyzed by Western blotting using 12CA5 to detect HA-tagged ubiquitin conjugates. The band that is present in all lanes is the PC11 antiserum Ig heavy chain detected by the second antibody. $(C)$ U2-OS cells were transfected with $5.0 \mu \mathrm{g} \mathrm{pRc}-\mathrm{E} 2 \mathrm{~F}-1$ and $3.0 \mu \mathrm{g}$ pRc-DP-1. Twentyfour hours after transfection, cells were incubated in medium supplemented with $10 \mu \mathrm{M}$ of the proteasome inhibitor Cbz-LLL (lanes 1-4), or medium with solvent only. After $12 \mathrm{hr}$ of incubation, cells were lysed and subjected to Western blot analysis with monoclonal antibody $\mathrm{KH} 20$. (D) U2-OS cells were transfected with $5.0 \mu \mathrm{g}$ pRc-E2F-1 and $3.0 \mu \mathrm{g}$ pRc-DP-1, together with $5.0 \mu \mathrm{g}$ of pMT123 (expressing HA-tagged ubiquitin protein), as indicated. Twenty-four hours after transfection, cells were incubated in medium supplemented with 10 $\mu \mathrm{M}$ of the proteasome inhibitor Cbz-LLL (lanes 1-4), or medium with solvent only. After $12 \mathrm{hr}$ of incubation, cells were lysed and subjected to immunoprecipitation with $\mathrm{mAb}$ KH95 and subsequently analyzed by Western blotting using 12CA5 to detect HA-tagged ubiquitin conjugates. The band that is present in all lanes is the KH95 Ig heavy chain detected by the second antibody. complexes may be required to maintain active transcriptional repression in quiescent cells that have low de novo synthesis of E2F-4 polypeptides. Cell cycle entry is accompanied by an increase in E2F transcription and an increase in free E2F transcription factor (Johnson et al. 1994b; Sardet et al. 1995). The rapid turnover of free E2F may prevent accumulation of excess free E2F, which is known to induce apoptosis (Qin et al. 1994; Wu and Levine 1994). That the cell has devised other mechanisms to limit the activity of E2F was shown recently. Cyclin A can interact directly with E2F-1, which mediates down-regulation of E2F DNA-binding activity during S phase (Dynlacht et al. 1994; Krek et al. 1994). Mutants of E2F-1 that are resistant to down-regulation by cyclin A induce apoptosis, probably by hyperstimulation of E2F-1-responsive genes (Krek et al. 1995). Our present data uncover another level of regulation of E2F transcrip- tion factors. By active degradation of free E2F, but not pocket protein-bound E2F, the cell inhibits degradation of E2F-pocket protein complexes in quiescent cells and prevents accumulation of high levels of free E2F in proliferating cells.

\section{Materials and methods}

Plasmids

pCMV-HA-E2F-1，pRc-E2F-1， pCMV-HA-DP-1， pCMV-E2F-1 (1-284), and pCMV-E2F-1 (1-374) were generous gifts of K. Helin (European Institute of Oncology, Milan, Italy). Mutant p107 expression vectors were provided by L. Zhu (Massachusetts General Hospital Cancer Center, Charlestown). pRc-HA-E2F-4 and $\mathrm{p} 5 \mathrm{Xhocc} 4$, expressing the entire early region 1 (E1) of adenovirus type 5 , have both been described previously (Bernards et al. 1982; Beijersbergen et al. 1995). p $\Delta \mathrm{E} 2 \mathrm{~F}-4$, expressing amino 
acids $1-310$ of E2F-4, was made by PCR and cloned in pRcCMV, downstream of an HA epitope. pMT123, expressing an HA-tagged ubiquitin protein, was kindly provided by D. Bohmann (Treier et al. 1994). pRc-DP-1 was a gift from M. Voorhoeve (Netherlands Cancer Institute, Amsterdam). pCMV-HA-p107 and pCMV-pRb have been described previously (Beijersbergen et al. 1994, 1995).

Cell culture, transfections, labeling and pulse-chase experiments

Human osteosarcoma U2-OS cells and human cervical carcinoma C33A cells were maintained in Dulbecco's modified Eagle's medium (DMEM) supplemented with $10 \%$ fetal calf serum (FCS). Transfections were performed overnight using the calcium phosphate method. After this, cells were refed with normal medium, and $36 \mathrm{hr}$ post-transfection, cells were either lysed directly in SDS-containing sample buffer to obtain whole cell lysates, or lysed in RIPA ${ }^{+}$(RIPA buffer supplemented with a cocktail of protease inhibitors, Complete, Boehringer Mannheim) and subjected to immunoprecipitations. For pulse-labeling and chase experiments in the presence or absence of pocket proteins or adenovirus El, cells were starved for $\mathrm{l} \mathrm{hr}$ in methionine-cysteine free medium and subsequently incubated with $100 \mu \mathrm{Ci}$ of $\left[{ }^{35} \mathrm{~S} /\right.$ methionine-cysteine per $100 \mathrm{~mm}$ dish for $2 \mathrm{hr}$. Then cells were lysed in RIPA ${ }^{+}$on ice for $30 \mathrm{~min}$ or incubated with normal medium supplemented with a 10-fold excess of nonradioactive methionine and cysteine for the indicated periods of time and lysed in RIPA ${ }^{+}$thereafter. Equal amounts of radioactive lysates were incubated at $4^{\circ} \mathrm{C}$ for $30 \mathrm{~min}$ with $5 \mu \mathrm{l}$ nonimmune serum for preclearing. Subsequently, lysates were incubated for $2 \mathrm{hr}$ at room temperature with specific antibodies, precomplexed on protein A-Sepharose beads. Immunoprecipitates were washed four times in RIPA, heated in SDS containing sample buffer, and loaded on a SDS- $7.5 \%$ polyacrylamide gel.

\section{Normalization of protein extracts for Western blot analysis}

To exclude differences in transfection efficiency and effects of transfected proteins on mRNA stability and to exclude effects caused by induction of apoptosis by E2Fs, protein extracts used in Western blots were normalized for mRNA levels present in transfected cell extracts. This was done as follows: $48 \mathrm{hr}$ after transfection, transfected cells were harvested and split in two. From one aliquot mRNA was isolated, from the other aliquot a protein extract was made for Western blot analysis. For Northern blot analysis (see below) equal amounts of total RNA were electrophoresed, blotted, and hybridized to an E2F cDNA probe. The relative intensities of the specific E2F transcripts were measured using a PhosphorImager. Subsequently, the amounts of protein extract loaded on the Western blot were normalized for mRNA levels. Thus, in every lane of the Western blot, an amount of protein is loaded that corresponds to a similar amount of E2F mRNA.

\section{Northern blotting}

Total RNA was isolated from transiently transfected cells $36 \mathrm{hr}$ post-transfection using the NP-40 lysis method. Equal amounts of RNA were separated on a $1 \%$ formaldehyde-agarose gel. After electrophoresis, RNA was transferred to a nitrocellulose filter and hybridized with a full-length E2F-1 or E2F-4 base pair 1-903 cDNA probes. Equal loading of the gel was checked by ethidium bromide staining.

\section{Immunoblotting}

For the abundance of E2F wild-type and E2F mutant proteins in the presence or absence of pocket proteins and adenovirus E1, whole cell lysates $(10 \%$ of a transiently transfected $100 \mathrm{~mm}$ dish/ were separated on SDS- $10 \%$ or SDS- $7.5 \%$ polyacrylamide gels, as indicated. Nonradioactive E2F immunoprecipitates, collected by protein A-Sepharose beads, were separated on a SDS$10 \%$ polyacrylamide gel. Proteins were transferred from gels to nitrocellulose filters by electrophoresis. Filters were blocked in PBS supplemented with $0.05 \%$ Tween- 20 and $5 \%$ nonfat milk (Protifar, Nutricia) (TPBS, 5\%) for $2 \mathrm{hr}$ at room temperature. Subsequently, filters were incubated with 12CA5 hybridoma supernatant (directed against the HA-tag) in a dilution of 1:200, or KH95 hybridoma supernatant (directed against the carboxyl terminus of E2F-1) in a dilution of $1: 10,000$, or with $\mathrm{KH} 20$ monoclonal antibody (directed against the amino terminus of E2F-1) in a dilution of 1:500, or with polyclonal E2F-4 antibody (C-108, Santa Cruz) in a dilution of 1:2000 for $3 \mathrm{hr}$ in TPBS, $1 \%$, at room temperature, and incubated with secondary antibody for $30 \mathrm{~min}$ at room temperature in TPBS, 1\%. Filters were washed three times in TPBS and visualization was performed by enhanced chemiluminescence (Amersham).

\section{E2F ubiquitination}

U2-OS cells were transiently transfected with $5 \mu \mathrm{g}$ pMT123 (HA-tagged ubiquitin), $5 \mu \mathrm{g}$ pRc-E2F, and $5 \mu \mathrm{g}$ pRc-DP-1 in different combinations. The total amount of transfected DNA per dish was adjusted up to $17 \mu \mathrm{g}$ with empty vector (pRc/CMV). Twenty-four hours post-transfection, cells were incubated overnight with the proteasome inhibitor Cbz-LLL in a final concentration of $10 \mu \mathrm{M}$ in DMEM and $10 \%$ FCS or refed with normal medium. After this, cells were lysed in RIPA ${ }^{+}$for 30 min on ice. Immunoprecipitations were performed with $2 \mu \mathrm{l} \mathrm{KH95} \mathrm{mono-}$ clonal antibody for E2F-1 and $2 \mathrm{ml}$ polyclonal E2F-4 antiserum for E2F-4. Transfer to nitrocellulose was performed overnight and the filter was incubated with $12 \mathrm{CA} 5$ hybridoma supernatant directed against HA-tagged ubiquitin.

To study the effect of proteasome inhibitor on E2F abundance, U2-OS cells were transiently transfected with $5 \mu \mathrm{g} \mathrm{pRc}$ E2F and $5 \mu \mathrm{g}$ pRc-DP-1, adjusted to $17 \mu \mathrm{g}$ with pRc/CMV or with $17 \mu \mathrm{g}$ empty vector. Twenty-four hours post-transfection, cells were incubated overnight with medium containing $10 \mu \mathrm{M}$ Cbz-LLL or refed with normal medium. Subsequently, cells were lysed directly in SDS-containing sample buffer, and the lysates were separated over a SDS- $10 \%$ polyacrylamide gel and immunoblotted with KH95 against E2F-1 protein or a polyclonal antiserum against E2F-4.

\section{Acknowledgments}

We are grateful to $\mathrm{K}$. Helin, D. Bohmann, L. Zhu, and $\mathrm{M}$. Voorhoeve for providing plasmids and antibodies. We also thank H. Ploegh and M. Bogyo for providing the proteasome inhibitor. This work was supported by grants from Dutch Cancer Society and the Netherlands Organization for Scientific Research.

The publication costs of this article were defrayed in part by payment of page charges. This article must therefore be hereby marked "advertisement" in accordance with 18 USC section 1734 solely to indicate this fact.

\section{References}

Beijersbergen, R.L. and R. Bernards. 1996. Cell cycle regulation 
by the retinoblastoma family of growth inhibitory proteins. Biochem. Biophys. Act 1287: 103-120.

Beijersbergen, R.L., R. Kerkhoven, L. Zhu, L. Carlée, P.M Voorhoeve, and R. Bernards. 1994. E2F-4, a new member of the E2F gene family, has oncogenic activity and associates with p107 in vivo. Genes \& Dev. 8: 2680-2690.

Beijersbergen, R.L., L. Carlée, R.M. Kerkhoven, and R. Bernards. 1995. Regulation of the retinoblastoma-related p107 by G1 cyclin complexes. Genes \& Dev. 9: 1340-1353.

Bernards, R., A. Houweling, P.I. Schrier, J.L. Bos, and A.J. Van der Eb. 1982. Characterization of cells transformed by Ad5/ Ad12 hybrid early region 1 plasmids. Virology 120: 422-432.

Botz, J., K. Zerfass-Thome, D. Spitkovsky, H. Delius, B. Vogt, M. Eilers, A. Hatzgerogiou, and P. Janssen-Durr. 1996. Cell cycle regulation of the murine cyclin E gene depends on an E2F binding site in the promoter. Mol. Cell. Biol. 16: 34013409.

Bremner, R., B.L. Cohen, M. Sopta, P.A. Hamel, C.J. Ingles, B.L. Gallie, and R.A. Phillips. 1995. Direct transcriptional repression by $\mathrm{pRb}$ and its reversal by specific cyclins. Mol. Cell. Biol. 15: 3256-3265.

Chau, V., J.W. Tobias, A. Bachmair, D. Marriott, D.J. Ecker, D.K. Gonda, and A. Varshavsky. 1989. A multiubiquitin chain is confined to specific lysine in a targeted short-lived protein. Science 243: 1576-1583.

Chittenden, T., D.M. Livingston, and I.A. DeCaprio. 1993. Cell cycle analysis of E2F in primary human $T$ cells reveals novel E2F complexes and biochemically distinct forms of free E2F. Mol. Cell. Biol. 13: 3975-3983.

Clurman, B.E., R.J. Sheaff, K. Thress, M. Groudine, and J.A. Roberts. 1996. Turnover of cyclin $\mathrm{E}$ by the ubiquitin-proteasome pathway is regulated by cdk2 binding and cyclin phosphorylation. Genes \& Dev. 10: 1979-1990.

Cobrinik, D., P. Whyte, D.S. Peeper, T. Jacks, and R.A. Weinberg. 1993. Cell cycle-specific association of E2F with the pl30 ElA-binding protein. Genes \& Dev. 7: 2392-2404.

Degregori, J., T. Kowalik, and J.R. Nevins. 1995. Cellular targets for activation by the E2Fl transcription factor include DNA synthesis- and Gl/S-regulatory genes. Mol. Cell. Biol. 15: 4215-4224.

Deshaies, R.J., V. Chau, and M.W. Kirschner. 1995. Ubiquitination of the G1 cyclin Cln $2 p$ by a Cdc $34 p$-dependent pathway. EMBO J. 14: 303-312

Dowdy, F.D., P.W. Hinds, K. Louie, S.I. Reed, and R.A. Weinberg. 1993. Physical interaction of the retinoblastoma protein with Human D cyclins. Cell 73: 499-511.

Dynlacht, B.D., O. Flores, J.A. Lees, and E. Harlow. 1994. Differential regulation of E2F transactivation by cyclin/cdk2 complexes. Genes \& Dev. 8: 1772-1786.

Ewen, M.E., H.K. Sluss, C.J. Sherr, H. Matsushime, J. Kato, and D.M. Livingston. 1993. Functional interactions of the retinoblastoma protein with mammalian D-type cyclins. Cell 73: 487-497.

Farnham, P.J., J.E. Slansky, and R. Kollmar. 1993. The role of $\mathrm{E} 2 \mathrm{~F}$ in the mammalian cell cycle. Biochim. Biophys. Acta 1155: 125-131.

Ginsberg, D., G. Vairo, T. Chittenden, Z.-X. Xiao, G. Xu, K.L. Wydner, J.A. DeCaprio, J.B. Lawrence, and D.M. Livingston. 1994. E2F-4, a new E2F transcription factor family member, interacts with pl07 and has transforming potential. Genes \& Dev. 8: 2665-2679.

Glotzer, M., A.W. Murray, and M.W. Kirschner. 1991. Cyclin is degraded by the ubiquitin pathway. Nature 349: 132-138.

Goebl, M.G., L. Goetsch, and B. Byers. 1994. The Ubc3 (Cdc34) ubiquitin-conjugating enzyme is ubiquitinated and phosphorylated in vivo. Mol. Cell. Biol. 14: 3022-3029.
Haas, A.L. and I.A. Rose. 1982. The mechanism of ubiquitin activating enzyme. A kinetic and equilibrium analysis. $J$. Biol. Chem. 257: 10329-10337.

Hateboer, G., E.M. Hijmans, J.B.D. Nooij, S. Schlenker, S. Jentsch, and R. Bernards. 1996. mUBC9, a novel adenovirus E1A-interacting protein that complements a yeast cell cycle defect. I. Biol. Chem. 271: 25906-25911.

Helin, K., J.A. Lees, M. Vidal, N. Dyson, E. Harlow, and A. Fattey. 1992. A cDNA encoding a pRB-binding protein with properties of the transcription factor E2F. Cell 70: 337-350.

Hiebert, S.W., M. Lipp, and J.R. Nevins. 1989. ElA-dependent trans-activation of the human MYC promoter is mediated by the E2F factor. Proc. Natl. Acad. Sci. 86: 3594-3598.

Hijmans, E.M., P.M. Voorhoeve, R.L. Beijersbergen, L.J. van 't Veer, and R. Bernards. 1995. E2F-5, a new E2F family member that interacts with pl30 in vivo. Mol. Cell. Biol. 15: 3082-3089.

Hilt, W. and D.H. Wolf. 1996. Proteasomes: Destruction as a programme. Trends Biochem. Sci. 21: 96-102.

Hinds, P.W., S. Mittnacht, V. Dulic, A. Arnold, S.I. Reed, and R.A. Weinberg. 1992. Regulation of retinoblastoma protein functions by ectopic expression of human cyclins. Cell 70: 993-1006.

Hochstrasser, M. 1995. Ubiquitin, proteasomes, and the regulation of intracellular protein degradation. Curr. Opin. Cell Biol. 7: 215-223.

Hofmann, F., F. Martelli, D.M. Livingston, and Z. Wang. 1996. The retinoblastoma gene product protects E2F-1 from degradation by the ubiquitin-proteasome pathway. Genes \& Dev. (this issue).

Jentsch, S. 1992. The ubiquitin-conjugation system. Annu. Rev. Genet. 26: 179-207.

Jentsch, S. and S. Schlenker. 1995. Selective protein degradation: A journey's end within the proteasome. Cell 82: 881884.

Johnson, D.G., W.D. Cress, L. Jakoi, and J.R. Nevins. 1994a. Oncogenic capacity of the E2F1 gene. Proc. Natl. Acad. Sci. 91: 12823-12827.

Johnson, D.G., K. Ohtani, and J.R. Nevins. 1994b. Autoregulatory control of E2Fl expression in response to positive and negative regulators of cell cycle progression. Genes \& Dev. 8: 1514-1525.

Kaelin, W.G., W. Krek, W.R. Sellers, J.A. DeCaprio, F. Ajchenbaum, C.S. Fuchs, T. Chittenden, Y. Li, P. Farnham, M.A. Blanar, D.M. Livingston, and E.K. Flemington. 1992. Expression cloning of a cDNA encoding a retinoblastoma-binding protein with E2F-like properties. Cell 70: 351-364.

Krek, W., M.E. Ewen, S. Shirodkar, Z. Arany, W.G. Kaelin Jr., and D.M. Livingston. 1994. Negative regulation of the growth promoting transcription factor E2F-1 by a stably bound cyclin A-dependent protein kinase. Cell 78: 161-172.

Krek, W., G. Xu, and D.M. Livingston. 1995. cyclin A-kinase regulation of E2F-1 DNA binding function underlies suppression of an S phase checkpoint. Cell 83: 1149-1158.

Lam, E.W. and R.J. Watson. 1993. An E2F-binding site mediates cell-cycle regulated repression of mouse B-myb transcription. EMBO I. 12: 2705-2713.

Lees, E., B. Faha, V. Dulic, S.I. Reed, and E. Harlow. 1992. Cyclin $\mathrm{E} / \mathrm{cdk} 2$ and cyclin A/cdk2 kinases associate with p107 and E2F in a temporally distinct manner. Genes \& Dev. 6: 1874 1885.

Neuman, E., E.K. Flemington, W.R. Sellers, and W.J. Kaelin. 1994. Transcription of the E2F-1 gene is rendered cell cycle dependent by E2F DNA-binding sites within its promoter. Mol. Cell. Biol. 14: 6607-6615.

Oswald, F., H. Lovec, T. Moroy, and M. Lipp. 1994. E2F-depen- 
dent regulation of human MYC: Trans-activation by cyclins $\mathrm{D} 1$ and $\mathrm{A}$ overrides tumour suppressor protein functions. Oncogene 9: 2029-2036.

Pagano, M., S.W. Tam, A.M. Theodoras, P. Beer-Romero, G. Del Sal, V. Chau, P.R. Yew, G.F. Draetta, and M. Rolfe. 1995. Role of the ubiquitin-proteasome pathway in regulating abundance of the cyclin-dependent kinase inhibitor p27. Science 269: 682-685.

Pickart, C.M. and I.A. Rose. 1985. Functional heterogeneity of ubiquitin carrier proteins. I. Biol. Chem. 260: 1573-1581.

Polyak, K., M.H. Lee, B.H. Erdjument, A. Koff, J.M. Roberts, P. Tempst, and J. Massague. 1994. Cloning of p27Kip1, a cyclindependent kinase inhibitor and a potential mediator of extracellular antimitogenic signals. Cell 78: 59-66.

Qin, X.Q., D.M. Livingston, W.J. Kaelin, and P.D. Adams. 1994. Deregulated transcription factor E2F-1 expression leads to S-phase entry and p53-mediated apoptosis. Proc. Natl. Acad. Sci. 91: 10918-10922.

Rock, K.L., C. Gramm, K. Rothstein, K. Clark, R. Stein, L. Dick, D. Hwang, and A.L. Goldberg. 1994. Inhibitors of the proteasome block the degradation of most cell proteins and the generation of peptides presented on MHC class I molecules. Cell 78: 761-777.

Rubin, D.M. and D. Finley. 1995. Proteolysis. The proteasome: A protein-degrading organelle? Curr. Biol. 5: 854-858.

Sardet, C., M. Vidal, D. Cobrinik, Y. Geng, C. Onufryk, A. Chen, and R.A. Weinberg. 1995. E2F-4 and E2F-5, two members of the E2F family, are expressed in the early phases of the cell cycle. Proc. Natl. Acad. Sci. 92: 2403-2407.

Scheffner, M., J.M. Huibregtse, R.D. Vierstra, and P.M. Howley. 1993. The HPV-16 E6 and E6-AP complex functions as a ubiquitin-protein ligase in the ubiquitination of p53. Cell 75: 495-505.

Schwob, E., T. Bohm, M.D. Mendenhall, and K. Nasmyth. 1994. The B-type cyclin kinase inhibitor p40SIC1 controls the G1 to $S$ transition in S. cerevisiae. Cell 79: 233-244.

Seufert, W., B. Futcher, and S. Jentsch. 1995. Role of a ubiquitinconjugating enzyme in degradation of S- and M-phase cyclins. Nature 373: 78-81.

Shirodkar, S., M. Ewen, J.A. DeCaprio, J. Morgan, D.M. Livingston, and T. Chittenden. 1992. The transcription factor E2F interacts with the retinoblastoma product and a p107-cyclin A complex in a cell cycle-regulated manner. Cell 68: 157166.

Singh, P., S.H. Wong, and W. Hong. 1994. Overexpression of E2F-1 in rat embryo fibroblasts leads to neoplastic transformation. EMBO J. 13: 3329-3338.

Toyoshima, H. and T. Hunter. 1994. p27, a novel inhibitor of G1 cyclin-Cdk protein kinase activity, is related to $\mathrm{p} 21$. Cell 78: 67-74.

Treier, M., L.M. Staszewski, and D. Bohmann. 1994. Ubiquitindependent c-Jun degradation in vivo is mediated by the delta domain. Cell 78: 787-798.

Vairo, G., D.M. Livingston, and D. Ginsberg. 1995. Functional interaction between E2F-4 and p130: Evidence for distinct mechanisms underlying growth suppression by different retinoblastoma protein family members. Genes \& Dev. 9: 869881.

Weintraub, S.J., C.A. Prater, and D.C. Dean. 1992. Retinoblastoma protein switches the E2F site from positive to negative element. Nature 358: 259-261.

Weintraub, S.J., K.N.B. Chow, R.X. Luo, S.H. Zhang, S. He, and D.C. Dean. 1995. Mechanisms of active transcriptional repression by the retinoblastoma protein. Nature 375: $812-$ 815.

Whyte, P., K.J. Buchkovich, J.M. Horowitz, S.F. Friend, M. Ray- buck, R.A. Weinberg, and E. Harlow. 1988. Association between an oncogene and an anti-oncogene: The adenovirus ElA proteins bind to the retinoblastoma gene product. $\mathrm{Na}$ ture 334: 124-129.

Wiertz, E.J.H.J., T.R. Jones, L. Sun, M. Bogyo, H.J. Geuze, and H.L. Ploegh. 1996. The human cytomegalovirus US11 gene product dislocates MHC class I heavy chains from the endoplasmic reticulum to the cytosol. Cell 84: 769-779.

Wu, X. and A.J. Levine. 1994. p53 and E2F-1 cooperate to mediate apoptosis. Proc. Nat1. Acad. Sci. 91: 3602-3606.

Yaglom, J., M.H. Linskens, S. Sadis, D.M. Rubin, B. Futcher, and D. Finley. 1995. p34Cdc28-mediated control of Cln3 cyclin degradation. Mol. Cell. Biol. 15: 731-741.

Zhu, L., S. van den Heuvel, K. Helin, A. Fattaey, M. Ewen, D. Livingston, N. Dyson, and E. Harlow. 1993. Inhibition of cell proliferation by p107, a relative of the retinoblastoma protein. Genes \& Dev. 7: 1111-1125.

Zhu, L., G. Enders, J.A. Lees, R.L. Beijersbergen, R. Bernards, and E. Harlow. 1995a. The pRB-related protein pl07 contains two growth suppression domains: Independent interactions with E2F and cyclin/cdk complexes. EMBO $I$. 14: 1904-1913.

Zhu, L., L. Zhu, E. Xie, and L.-S. Chang. 1995b. Differential roles of two tandem E2F sites in the repression of the human p107 promotor by retinoblastoma and p107 proteins. Mol. Cell. Biol. 15: 3552-3562. 


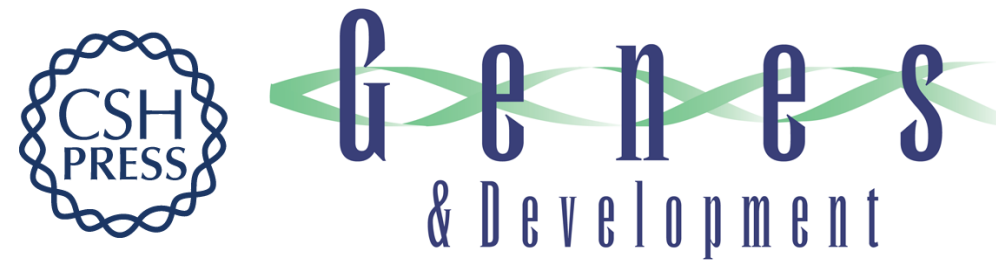

\section{Degradation of E2F by the ubiquitin-proteasome pathway: regulation by retinoblastoma family proteins and adenovirus transforming proteins.}

G Hateboer, R M Kerkhoven, A Shvarts, et al.

Genes Dev. 1996, 10:

Access the most recent version at doi:10.1101/gad.10.23.2960

References This article cites 62 articles, 29 of which can be accessed free at:

http://genesdev.cshlp.org/content/10/23/2960.full.html\#ref-list-1

License

Email Alerting Service

Receive free email alerts when new articles cite this article - sign up in the box at the top right corner of the article or click here.

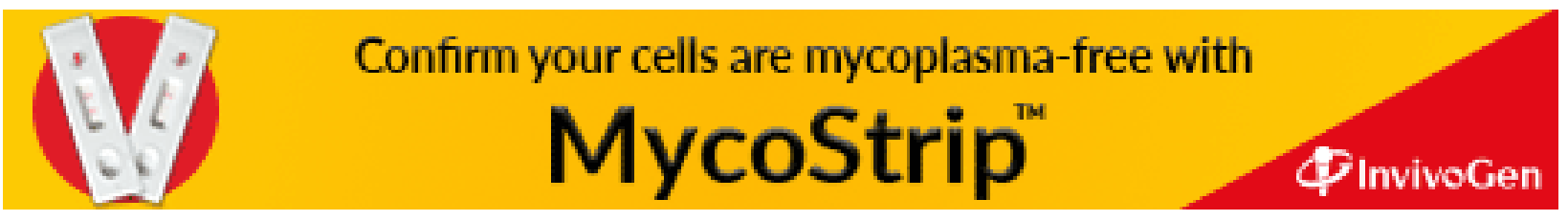

